\section{Sox1 directly regulates the $\gamma$-crystal lin genes and is essential for lens development in mice}

\author{
Seiji Nishiguchi, ${ }^{1}$ Heather Wood, ${ }^{1}$ Hisato Kondoh, ${ }^{2}$ \\ Robin Lovell-Badge, ${ }^{3}$ and Vasso Episkopou ${ }^{1,4}$ \\ ${ }^{1}$ Laboratory of Embryology, Medical Research Council (MRC) \\ Clinical Sciences Centre, Hammersmith Hospital, London \\ W12 ON N, UK; ${ }^{2}$ Institute for M olecular and Cellular Biology, \\ Osaka University, Suita, Osaka 565, Japan; ${ }^{3}$ Division of \\ Devel opmental Genetics, MRC National Institute for M edical \\ Research, London, NW7 IAA, UK
}

$\gamma$-Crystallins are major structural components of the lens fiber cells in amphibians and mammals. Many dominant inherited cataracts in humans and mice have been shown to map within the $\gamma$-crystal lin gene cluster. Several transcription factors, including PAX6 and SOX proteins, have been suggested as candidates for crystallin gene regulation. Here we show that the targeted deletion of Sox 1 in mice causes microphthalmia and cataract. Mutant lens fiber cells fail to elongate, probably as a result of an almost complete absence of $\gamma$-crystallins. It appears that the direct interaction of the SOX1 protein with a promoter element conserved in all $\gamma$-crystallin genes is responsible for their expression.

Received N ovember 28, 1997; revised version accepted January 21, 1998.

The normal differentiation of the lens into a transparent structure involves changes in cell organization and shape as well as the synthesis of several classes of abundant Iens-specific proteins, the crystallins. The anterior cells of the lens vesicle constitute a monolayer germinal epithelium. The posterior cells of the lens vesicle-those that are closer to the retina-stop dividing, elongate throughout most of the diameter of the lens, and fill the cavity of the lens vesicle.

Crystallins constitute $90 \%$ of the soluble protein in lens fiber cells (de Jong 1981) and they are divided into several classes. These include the conserved $\alpha$ - and $\beta$ crystallins, which are found in all major vertebrate species, and those that are taxon specific (Wistow and Piatigorsky 1988), such as $\gamma$-crystallins, which are found in amphibians and mammals, and $\delta$-crystallin, which is found in birds and reptiles. Although there are many conserved and diverse crystallin genes, they are all expressed in the lens with spatial and temporal expression patterns characteristic for each class (McAvoy 1978; Wistow and Piatigorsky 1988). It has been postulated

[Key Words: Sox1; gene targeting; cataract; $\gamma$-crystallin] ${ }^{4} \mathrm{C}$ orresponding author.

E-MAIL vepiskop@rpms.ac.uk; FAX 44-181-383-8338. that the genes are control led by common factors. Several transcription factors have been suggested as candidates for crystal lin gene regulation, including PAX6 and SOX proteins (Cvekl and Piatigorsky 1996).

The mammalian Pax6 gene and its Drosophila homolog eyeless have been shown to play a critical role in vertebrate and invertebrate eye devel opment. M isexpression of Pax6 or eyeless leads to the development of ectopic eyes in Drosophila (Halder et al. 1995). Mutations in Pax6 cause Aniridia in humans and Small eye syndrome in mice (Hill et al. 1991; T on et al. 1991; Glaser et al. 1994). Recently, more genes involved in eye development have been identified and shown to be conserved in diverse species (Oliver and Gruss 1997).

The testis determining gene Sry is the founder member of the Sox family of genes, which encode transcription factors containing an HMG box type of DNA-binding domain (Gubbay et al. 1990; for review, see Pevny and Lovell-Badge 1997). The subfamily group B genes Sox1, Sox2, and Sox3 encode proteins with a considerable degree of overall sequence similarity, especially within their HMG box domains, which are $96 \%$ identical to each other (Collignon et al. 1996). They are expressed from early embryonic stages in a largely overlapping manner within the CNS, but in addition, each gene is expressed uniquely in some sites (Collignon 1992; Uwanogho et al. 1995; Collignon et al. 1996; Streit et al. 1997). In mice, Sox 2 is expressed in all sensory placodes, including that which gives rise to the lens. However, Sox2 expression is down-regulated once the lens vesicle has formed and is replaced by Sox 1 in this site (Collignon 1992). It has been shown that in chicken lens explants SOX protein binding is essential for lens-specific activity of the chicken $\delta 1$-crystallin enhancer as well as the mouse $\gamma$ F-crystallin promoter (Kamachi et al. 1995).

We deleted the Soxl gene in mice by gene targeting and found that mice homozygous for the mutation have small eyes with opaque lenses. Although Soxl-deficient mice are viable, they suffer from spontaneous seizures; this aspect of the phenotype is not yet understood. We show that in the mutant eyes, the elongation of Iens fi ber cells is impaired and $\gamma$-crystallin gene expression is severely down-regulated. We also show that Sox 1 protein binds to a promoter element that is conserved in all $\gamma$ and $\delta$-crystallin genes and that has been shown to be essential for expression in vitro. Sox 1 is therefore a critical gene in mammalian lens development, at least partly through its direct action on $\gamma$-crystallin gene expression.

\section{Results and Discussion}

We used targeted mutagenesis in embryonic stem (ES) cells to delete the major part of the Soxl gene that encodes for the HMG box and the entire carboxy-terminal domain (Fig. 1). M ice heterozygous for the Sox1 deletion did not exhibit any obvious abnormalities and were fertile. M ice homozygous for the mutation were born with 
the expected Mendelian frequency in both an inbred 129 /Sv and hybrid (mainly 129/Sv $\times$ MF1) background, indicating that Sox 1 is not essential for embryonic life. However, homozygous mice are microphthalmic, suffer from spontaneous seizures, and show high mortality in both genetic backgrounds. The surviving homozygotes of both sexes rarely mate and are unfit to care for their offspring.

Consistent with the expression pattern of Sox 1 during eye development, histological analysis of Sox1 mutant eyes at different stages revealed abnormal lens development (Fig. 2). Normally, the posterior cells of the lens vesicle, those that are closer to the retina, stop dividing, elongate throughout most of the diameter of the lens, and fill the cavity of the lens vesicle (Fig. 2A,C,E). In the mutant lens, induction and fiber cell differentiation occur normally but the fiber cells fail to el ongate all the way toward the anterior epithelial wall, leaving a cavity within the lens vesicle (Fig. 2B,D,F). The size of the mutant lens is reduced by $\sim 20 \%$; at 15.5 days postcoitum (dpc) the diameter of the lens was $550 \pm 20 \mu \mathrm{m}$ (mean \pm S.D. $)$ in the wild-type $(n=4)$ and $430 \pm 50 \mu \mathrm{m}$ in the mutant $(n=4)$. This correlates with a similar reduction of cell number in the mutant lens. As Sox1, Sox2, and Sox3 are mainly expressed in the dividing neural epithelium in the CNS (Collignon et al. 1996), it is possible that they may be involved in mitotic activity. To explain the reduction in size and cell number of the mutant lens we performed BrdU incorporation assays at 12.5 and 15.5 dpc (Fig. 2G-K). We did not find any significant difference in the mitotic activity of cells in the anterior ger-
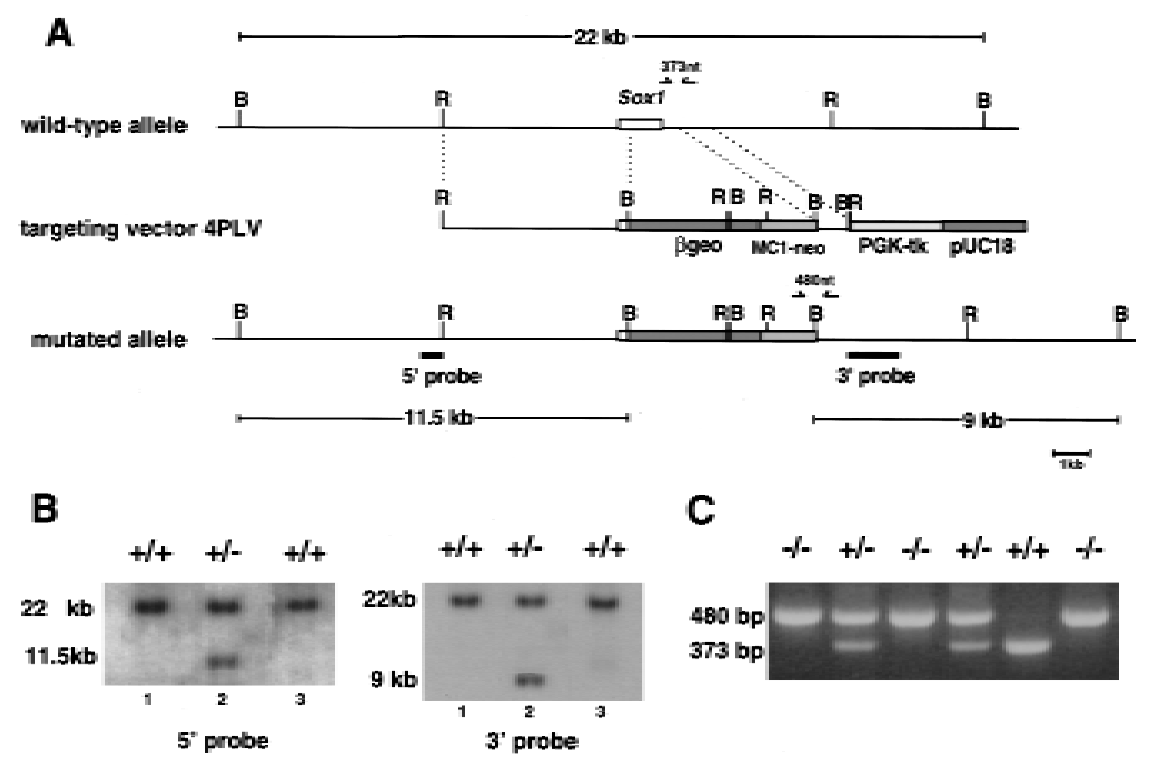

Figure 1. Targeted disruption of the Soxl gene. (A) The structure of the wild-type allele, targeting vector, and targeted allele are shown together with the restriction sites. The open box represents Sox 1 coding sequence. The sizes of DN A fragments from the wildtype and mutated allele detected by the $5^{\prime}$ and $3^{\prime}$ probes are indicated. The positions of the PCR primers for genotyping are shown as arrows above the gene. (B) BamHI; (R) EcoRI. (B) Southern blot analysis of BamHI-digested DNA from ES cell clones using 5' and 3' probes, (Lanes 1,3) Wild-type ES cells; (lane 2) targeted ES cells. (C) PCR analysis of offspring derived from a mating of mice heterozygous for Soxl deletion. minal epithelium between wild-type and mutant lens; at $15.5 \mathrm{dpc}$ the proliferative index, which is the ratio of proliferating cells (BrdU-positive nuclei) to the total number, was the same in wild-type $(0.222 \pm 0.023$ in three embryos) and mutant (0.223 \pm 0.016 in three emryos) anteri or germinal epithelium. Surprisingly, we obsignificant BrdU incorporation, in the $15.5 \mathrm{dpc}$ mutant ens (Fig. 2J,K). We conclude that the absence of Soxl is not important for proliferation in the anterior germinal difference in size and cell number between mutant and wild-type lens is a secondary event (cell death or degenhow any lens defects or late onset cataracts.

The time when the lens defect first becomes apparent correlates with the commencement of crystallin gene 1992). This coincides with the up-regulation of Sox1 expression and concomitant down-regulation of Sox2 (Fig. 3). We examined the expression of most crystallin genes eyes of the Sox1 mutant embryos using an RT(Fig. 4). We did not find any significant difference in expression of both $\alpha$-class genes ( $\alpha \mathrm{A}$ and $\alpha \mathrm{B})$ nor of the two genes from the $\beta$-class we have examined.

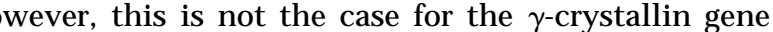
$\gamma \mathrm{B}, \gamma \mathrm{C}, \gamma \mathrm{D}, \gamma \mathrm{E}$, and $\gamma \mathrm{F}$. The time of activation of the cluster is 12.5 dpc in normal lenses (Goring et al. 1992) although we found that $\gamma \mathrm{C}$ is activated a day earlier (data not shown) and $\gamma \mathrm{D}$ later than 12.5 dpc. At $12.5 \mathrm{dpc}$, we found that $\gamma \mathrm{A}$ and $\gamma \mathrm{B}$ gene transcripts are undetectable while $\gamma \mathrm{F}$ is present at a low level in the mutant lens. However, by $\mathbf{1 5 . 5}$ dpc, all the $\gamma$-crystallin genes are down-regulated, including $\gamma \mathrm{C}$ and $\gamma \mathrm{E}$, that were unaffected at $12.5 \mathrm{dpc}$. At this stage, this down-regulation is not a secondary event due to the small size of the lens or lens-cell degeneration as the expression of the other lens-specific crystallin classes $\alpha$ - and $\beta$ - in the mutant eye is unaffected. Within the limits for quantitation of the RT-PCR assay, we do not see a reduction in $\gamma$-crystallin gene expression in heterozygous mice. This is in contrast with other SOX mutations that show haploid insufficiency, such as in human SOX9, where heterozygotes invariably show campomelic dysplasia (Foster et al. 1994).

In vitro experiments using chicken lens explants showed that SOX2 protein binding is required for lens-specific activity of the chicken $\delta 1$-crystallin enhancer as well as the mouse $\gamma$ F-crystallin promoter (Kamachi et 


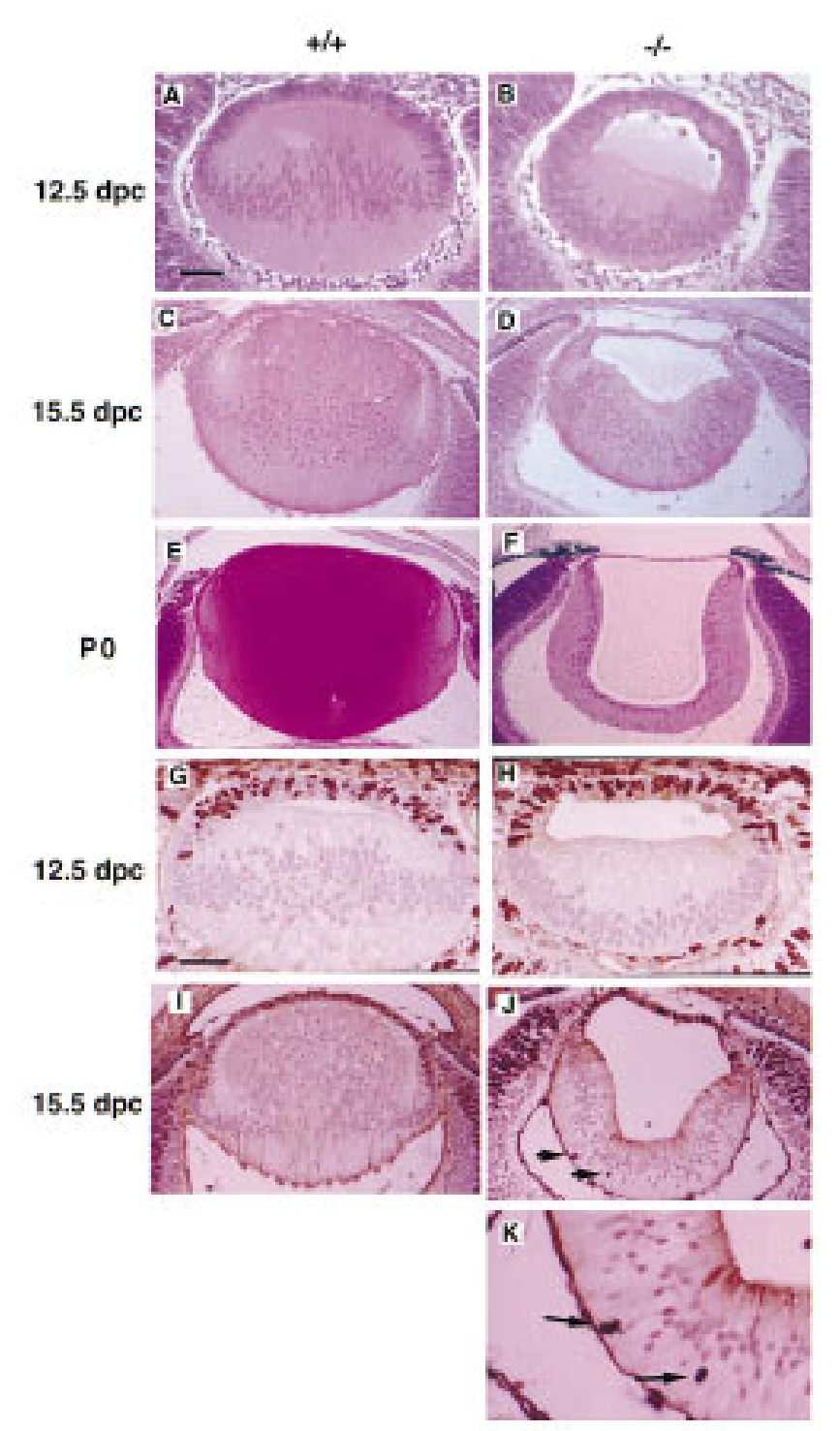

Figure 2. Histological analysis and cellular proliferation of wild-type and mutant lens. Hematoxylin and eosin staining of embryonic lens: $(A, C, E)$ Wild-type lens, $(B, D, F)$ mutant lens at $12.5 \mathrm{dpc}(\mathrm{A}, \mathrm{B}), 15.5 \mathrm{dpc}(\mathrm{C}, \mathrm{D})$, and postnatal day zero $(\mathrm{PO})(\mathrm{E}, \mathrm{F})$. Loss of Sox 1 causes impaired posterior lens fiber cell el ongation and small, hollow lens. The nuclei in the mutant lens fiber cells are located closer to the retinal side at $12.5 \mathrm{dpc}$, whereas at P0, they are located closer to the cavity of the lens. BrdU incorporation assays: $(\mathrm{G}, \mathrm{I})$ Wild-type lens; $(\mathrm{H}, \mathrm{J}, \mathrm{K})$ mutant lens at 12.5 $\mathrm{dpc}(\mathrm{G}, \mathrm{H})$ and $15.5 \mathrm{dpc}(\mathrm{I}-\mathrm{K})$. Arrows indicate BrdU-positive nuclei in the lens fiber cells. Bar, $50 \mu \mathrm{m}$ in A, B, G, and H; 100 $\mu \mathrm{m}$ in $\mathrm{C}$ and $\mathrm{D} ; 140 \mu \mathrm{m}$ in $\mathrm{E}$ and $\mathrm{F} .120 \mu \mathrm{m}$ in I and J; $50 \mu \mathrm{m}$ in $\mathrm{K}$.

al. 1995). However, Sox1 expression persists in the developing mouse lens long after the Sox 2 gene is silent (Fig. 3). Furthermore, there is evidence that mouse SOX1 activates the $\gamma \mathrm{F}$-crystallin promoter better than SOX2 in chicken lens explants ( $Y$. Kamachi and $\mathrm{H}$. Kondoh, pers. comm.). SOX2 binds to an element that is essential for activation of the $\gamma \mathrm{F}$-crystallin promoter in chicken lens explants (Kamachi et al. 1995). This element is con- served in all $\gamma$-crystallin promoters (Kamachi et al. 1995) and contains a consensus SOX binding site (Lok et al. 1989; Pevny and Lovell-Badge 1997) (Fig. 5A). We there fore performed EM SAs using recombinant SOX 1 protein to show that SOX 1 binds specifically to this site (Fig. 5B). Incubation of SOX1 with the mouse $\gamma \mathrm{A}$-crystallin promoter element produced a protein-DNA complex. This binding is sequence-specific as it was competed by an excess of wild-type $\gamma \mathrm{A}$-crystallin oligonucleotide but not by a mutated one $(\gamma A M)$, in which the consensus SOX binding site sequence is disrupted (Fig. 5B). In addition, the specific signal is no longer detected in the EMSA when anti-SOX1 antiserum abFB43 or ab791 is added. We conclude from both our in vitro and in vivo data that $\gamma$-crystal lin genes are direct targets for SOX 1 .

Our data show that SOX1 is essential for activation of some $\gamma$-crystallin genes and for maintaining expression of all of them. The two genes, $\gamma \mathrm{C}$ and $\gamma \mathrm{E}$, that are expressed at $12.5 \mathrm{dpc}$ in the Sox 1 mutant lens may have been activated by SOX2. This is possible as SOX1 and SOX 2 proteins have similar properties in vitro (Kamachi et al. 1995; Collignon et al. 1996). In addition, we find that SOX 2 protein is present in the lens-pit nuclei at 10.5 $\mathrm{dpc}$ and in some nuclei of the lens fiber cells at $12.5 \mathrm{dpc}$ (Fig. 3). However, by $15.5 \mathrm{dpc}$, we cannot detect SOX2 protein in the nuclei of the fiber cells (Fig. 3). Therefore, in the Sox 1 mutant lens, all genes within the entire $\gamma$ crystallin gene cluster are turned off coincident with the loss of SOX2 protein within lens fiber nuclei. The notion that $\mathrm{SOX} 1$ and $\mathrm{SO} \times 2$, and presumably $\mathrm{SO} \times 3$ may be functionally redundant with respect to each other is al so supported by the finding that they can bind to the same DN A sequences (Pevny and Lovel I-Badge 1997), and it is consistent with our observation that loss of SOX1 does not have any obvious consequences during early development of the CNS. A nother example of functional redundancy within the SOX genefamily is provided by the Sox4 gene disruption in mice. This causes major abnormalities only in cardiac and pro-B-lymphocyte development al though the gene is expressed in many other sites in the embryo (Schilham et al. 1996).

The delay of fiber cell elongation in the mutant coincides with the down-regulation of $\gamma$-crystal lin genes. The $\gamma$-crystallin deficit is probably responsible for the incomplete elongation of the lens fibers. This could be explained by the theory that fiber cell elongation may be controlled osmotically by the protein concentration inside the cell (Parmelee and Beebe 1988). However, targeted disruption of the mouse $\alpha \mathrm{A}$-crystall in gene, which is al so a major crystallin, does not affect fiber elongation and mice have normal but smaller lens (Brady et al. 1997). In this case, there may be an up-regulation of $\alpha \mathrm{B}$ crystallin gene expression that partially compensates for the loss of $\alpha \mathrm{A}$. Alternatively, crystal lins may have additional nonrefractory functions, like architectural and intracellular functions important for the differentiation of the lens fiber cells (Piatigorsky and Wistow 1989; Brady et al. 1997). This theory has been supported by the discovery that $\alpha$-crystallin functions as a chaperone in vitro (Horwitz 1992). Another example of the involvement of 

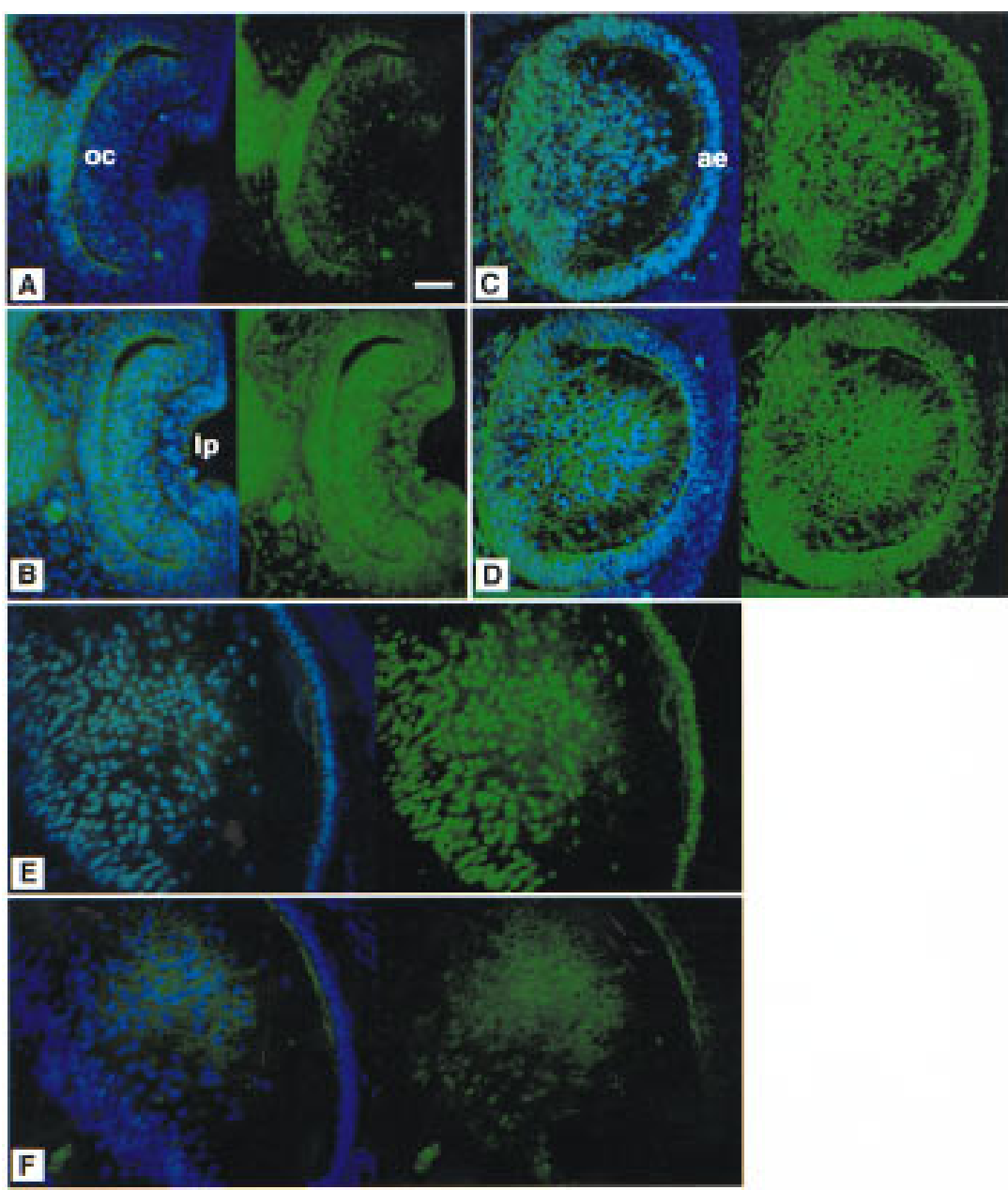

Figure 3. Immunofluorescent analysis of the wild-type lens. Eye sections at 10.5 $(A, B), 12.5$ (C,D), and 15.5 (E,F) dpc. (A,C,E) SOX1 and (B,D ,F) SOX2 expression. The left of each panel shows the DAPI nuclear counterstain (blue) with SOX protein expression patterns (green); the right shows protein expression only. SOX1 protein can be detected in the nuclei of the presumptive lens fibers later during day 10 of devel opment (not shown). SOX2 protein is detected in the nuclei of the cells of both the optic cup and the lens pit at $10.5 \mathrm{dpc}(\mathrm{B})$. At $12.5 \mathrm{dpc}$, SOX 1 is present in the nuclei of the developing lens fibers and the anterior epithelium (C); anti-SOX2 predominantly stains the cytoplasm of the lens fibers (D), although the protein is sometimes detected in the nuclei of the less differentiated lens fiber cells around the equatorial region and in the anterior epithelium (not shown). At $15.5 \mathrm{dpc}$ in the lens, SOX 1 is still detected in fiber cell nuclei (E), but SOX2 protein is absent (F). (OC) Optic cup; (Ip) lens pit; (ae) anterior epithelium. Bar, $50 \mu \mathrm{m}$.

$\gamma$-crystallins in developmental functions is the Elo mouse (Cartier et al. 1992), in which only the $\gamma \mathrm{E}$-crystallin gene is mutated. The phenotype has much in common with the lens abnormal ity in the Sox 1 mutant mice as it also affects fiber cell elongation and causes microphthal mia. Although the $\gamma \mathrm{E}$ mutation is dominant, it is possible that it acts in a dominant-negative fashion. In addition, the effects of SOX1 on other genes important for differentiation, architecture, and survival of the lens fiber cells might contribute to the overall phenotype of the lens.

Binding of SOX proteins to the target DNA induces dramatic bends; therefore, it has been suggested that they function as architectural factors. N evertheless, SOX proteins share several characteristics with classical transcription factors and putative transactivation domains have been mapped for several of them, including SOX1 (see Pevny and Lovell-Badge 1997 and references therein). Further analysis of the Soxl mutant mice will allow us to understand the mechanism of its action and learn more about the functional interchangeability with other SOX proteins.

Finally, it is important to emphasize that the Soxl mutant mice could be a useful tool in studying lens development and in investigating the role of $\gamma$-crystallins in lens development and in cataracts. The $\gamma$ crystallin gene cluster has been shown to be linked to the Coppock like cataract in humans (Lubsen et al. 1987) and the Cat$2^{\mathrm{t}}, \mathrm{No}$, and Tol mutations in mice (Everett et al. 1994). We have cloned the human SO $\times 1$ gene and mapped it to chromosome $13 q 34$ (Malas et al. 1997); this locus should now be examined for linkage with similar abnormalities in humans.

\section{Materials and methods}

Targeting vector and gene disruption

The replacement targeting vector 4PLV was designed to delete all of the coding region of Sox1 except for that encoding the first 56 amino acids. Smal and Notl sites of $p \beta g e o$ (gift from P. Soriano, Fred Hutchinson Cancer Research Center, Seattle, WA) were converted to Bglll and a 3.9-kb Bglll-Bglll fragment containing its own translation start site was cloned into a BgllIconverted $\mathrm{Xmnl}$ site of the Sox 1 coding region. The $1.5-\mathrm{kb}$ Xhol-Xhol fragment of this vector, which contains the Sox 1 coding region, was replaced with a 1.1$\mathrm{kb}$ Xhol-Sall fragment from pMC1neopolyA (Stratagene) in the forward direction. For 4PLV, the 8.0-kb $\mathrm{Kpnl}-\mathrm{Xbal}$ fragment of this vector, the $5.7-\mathrm{kb} \mathrm{Xbal}-$ Xhol fragment from pPNT (gift from V. Tybulewicz, MRC, NIM R, London, UK), and the 5.5-kb Xhol-Kpnl fragment from the Sox $15^{\prime}$ homologous region were ligated. This targeting vector was linearized and introduced into CCE ES by electroporation. Double selection in G418 and Gancyclovir produced 465 clones that were analyzed by Southern blotting using probes from outside the $3^{\prime}$ and 5 ' regions of the targeted area. Three clones bearing a disrupted Soxl gene were injected into C57BL/ 6 embryos and passed into the germ line. LacZ activity was not detected, possibly because translation does not initiate from the translation start site of $\beta$ geo.

Histological analysis of mutant mice

Embryos and adult eyes were fixed in 4\% paraformal dehyde in PBS overnight at $4^{\circ} \mathrm{C}$, transferred to $50 \mathrm{~mm}$ sucrose, $50 \mathrm{~mm}$ glycine, and $100 \mathrm{~mm}$ phosphate buffer at $4^{\circ} \mathrm{C}$ until equilibrated, dehydrated, cleared in Histoclear, and embedded in paraffin. Embedded samples were sectioned at 7 $\mu \mathrm{m}$. Embryos were genotyped by PCR of yolk-sac DNA using 5' sense primers SX3FN ew, 5'-TTACTTCCCGCCAGCTCTTC-3' (which binds the wild-type allele), neo2, 5'-CTTCCTCGTGCTTTACGGTATCGC-3' (which binds the mutated allele), and the $3^{\prime}$ common antisense primer SX1 3'R, 5'-TGATGCATTTTGGGGGTATCTCTC-3'. SX3FN ew and SX1 3'R detect a 373-bp fragment indicative for the wild-type allele, and 


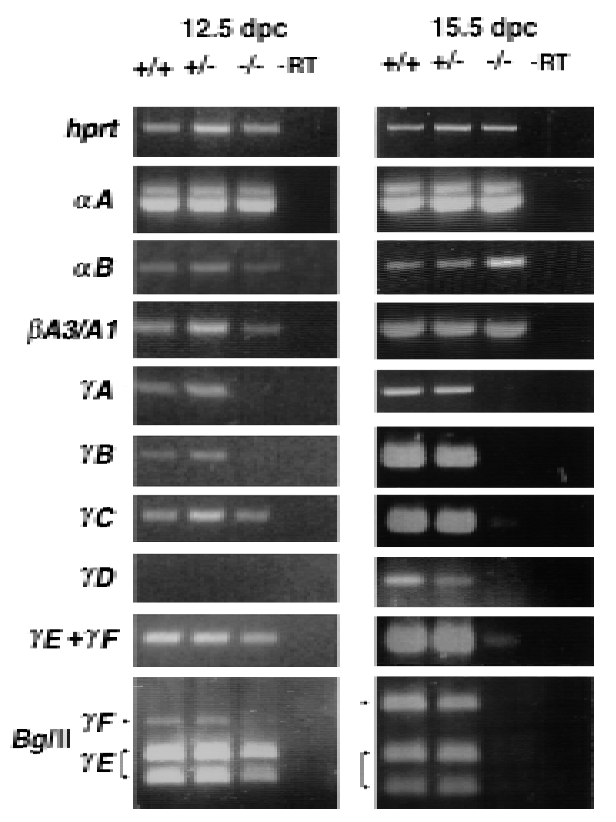

Figure 4. Crystallin gene-expression study of wild-type and mutant lens. RT-PCR analysis of hprt, $\alpha \mathrm{A}-, \alpha \mathrm{B}-, \beta \mathrm{A} 3 / \mathrm{A} \mathrm{1}_{-}, \gamma \mathrm{A}-$, $\gamma \mathrm{B}-, \gamma \mathrm{C}-, \gamma \mathrm{D}-, \gamma \mathrm{E}-$, and $\gamma \mathrm{F}-\mathrm{crystallins}$ at 12.5 and $15.5 \mathrm{dpc} . \alpha \mathrm{B}-$ Crystallin expression in the Sox 1 mutant eye at $15.5 \mathrm{dpc}$ is up-regulated possibly due to hypertonic stress (Dasgupta et al. 1992).

neo2 and SX1 3'R detect a 480-bp fragment indicative of the mutated allele.

\section{BrdU labeling of embryos}

For BrdU assays, pregnant mice from heterozygote matings were injected with $\mathrm{BrdU}(0.1 \mathrm{mg} / \mathrm{gram}$ of body weight) $1 \mathrm{hr}$ before caesarean section. Embryos were dissected and fixed in $4 \%$ paraformal dehyde overnight at $4^{\circ} \mathrm{C}$, dehydrated, cleared, and embedded in paraffin. Sections were cut at $7 \mu \mathrm{m}$, incubated in $3 \% \mathrm{H}_{2} \mathrm{O}_{2}$ for $10 \mathrm{~min}$, denatured in $2 \mathrm{~N} \mathrm{HCl}$ for $30 \mathrm{~min}$, digested with $0.1 \%$ trypsin for $5 \mathrm{~min}$ at $37^{\circ} \mathrm{C}$, each followed by washing in PBS for $5 \mathrm{~min}$, and stained with an anti-BrdU monoclonal antibody (Dako) diluted 1:50 for $1 \mathrm{hr}$ at $37^{\circ} \mathrm{C}$. A Vectastain Elite kit (Vector Laboratories) was used for final antigen detection using DAB and hydrogen peroxide. The sections were counterstained with hematoxylin.

Immunohistochemistry

Embryos were fixed overnight in $95 \%$ ethanol $/ 1 \%$ acetic acid at $4{ }^{\circ} \mathrm{C}$ dehydrated through graded ethanols, cleared in histoclear, and embedded in paraffin. Embedded samples were sectioned at $10 \mu \mathrm{m}$, dewaxed, rehydrated, and incubated with primary antibodies overnight at $4^{\circ} \mathrm{C}$. Rabbit anti-mouse SOX 1 antiserum abFB43 and anti-mouse SOX 2 abFB46 were diluted to 1:500. Antigen-antibody complexes were detected by incubating with FITC-conjugated goat anti-rabbit IgG (Sigma) for $30 \mathrm{~min}$ at room temperature. Sections were counterstained with DAPI.

\section{RT-PCR amplification}

Eyes were dissected from 12.5 and $15.5 \mathrm{dpc}$ embryos derived from matings between mice heterozygous for Sox1 deletion and frozen down individually. After genotyping the embryos by PCR, total RNA was isolated (Biogenesis; RNAzol B) from eight eyes for each genotype. One microgram was used for CDN A synthesis using M -M LV reverse transcriptase (BRL) and random hexamer primers. One-twentieth of this reaction was used as a template for PCR amplification with DYNAZyme II (Finzyme OY) using the following crystallin primers: $\alpha A$, 5'-GACTGTTCGACCAGTTCTTCGG-3' (located in exon 1) and 5'-GAAGGTCAGCATGCCATCAGC-3' (exon 3); $\alpha$ B, 5'-TTCCAGAAGCTTCAGAAGACTGC-3' (exon 1) and 5'-AAGTGATGGTGAGAGGATCCAC-3' (exon 3); $\beta A 3 / A 1,5^{\prime}$-TTATGAACACACCAGCTTCTGTG-3' (exon 3) and 5'-TTAGCAAGATGTCATGCTTGAGG-3' (exon 5); $\gamma$ A, GUNIVF 5'-CTGCTGGATGCTCTATGAGC-3' (exon 2) and GAR 5'-CTGTAA-
CAAGCAAAAGGAGGC-3' (exon 3); $\gamma$ B, GUNIVF (exon 2) and GBR 5'-CAACCTTGGCATTTGCAGCC-3' (exon 3); $\gamma$ C, GUNIVF (exon 2) and GCR 5'-TTGCAGCGAGCGCACCTCAC-3' (exon 3); $\gamma$ D, GUNIVF (exon 2) and GDR 5'-TTCCGTGAACTCTATCACTTGGC-3' (exon 3); $\gamma$ EF, GUNIVF (exon 2) and GEFR 5'-CGTGGAAGGAGTGGAAGTCAC3' (exon 3); hprt primers, hprt41 5'-GGCTTCCTCCTCAGACCGCTTT$3^{\prime}$ and hprt742 5'-AGGCTTTGTATTTGGCTTTTCC-3'. All sets of primers for RT-PCR were designed to bracket an intron(s). Primers for $\gamma$-crystallins are based on a previous study (Goring et al. 1992). PCR was carried out at $94^{\circ} \mathrm{C}$ for $30 \mathrm{sec}, 62^{\circ} \mathrm{C}$ (for $\alpha \mathrm{A}-, \alpha \mathrm{B}$-, and $\beta \mathrm{A} 3 / \mathrm{A} 1$-crystallins) or $63^{\circ} \mathrm{C}$ (for $\gamma \mathrm{A}-, \gamma \mathrm{B}-, \gamma \mathrm{C}-, \gamma \mathrm{D}-$, and $\gamma \mathrm{EF}$-crystallins) or $55^{\circ} \mathrm{C}$ (for hprt) for $30 \mathrm{sec}$, and $72^{\circ} \mathrm{C}$ for $1 \mathrm{~min}$ for $30 \mathrm{cycles}$. Because of close sequence similarity, $\gamma \mathrm{E}$ - and $\gamma \mathrm{F}$-crystall in genes were amplified with the same set

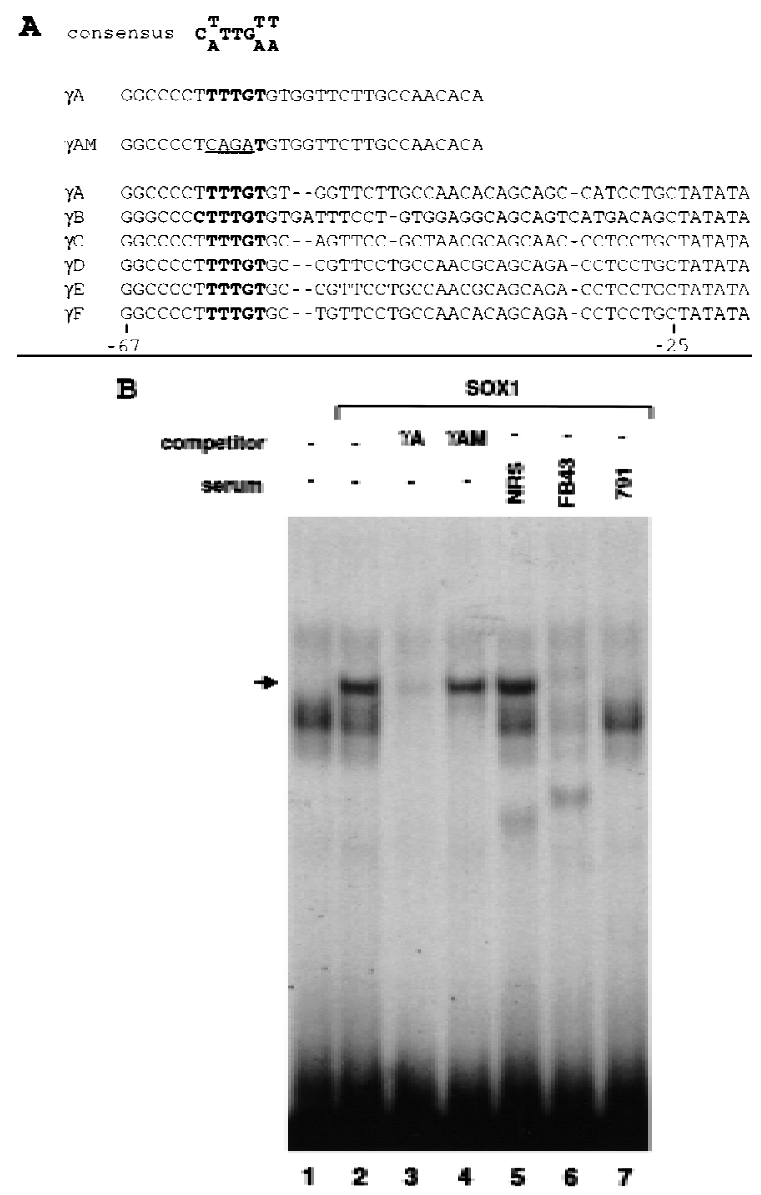

Figure 5. Binding of $\mathrm{SOX} 1$ protein to the mouse $\gamma \mathrm{A}$-crystallin promoter. (A) Complementary strand of SOX binding consensus sequence, wild-type $(\gamma \mathrm{A})$, and mutated $(\gamma \mathrm{AM})$ oligonucleotide sequence from the $\gamma \mathrm{A}$-crystallin promoter that was used for EMSA, promoter-sequence alignment of the six mouse $\gamma$-crystallin genes. Sequences identical to the consensus SOX binding site are shown in boldface type. The substituted nucleotides in $\gamma \mathrm{AM}$ are underlined. Nucleotide positions of the $\gamma \mathrm{F}$-crystallin gene relative to the transcription start site are shown. (B) EMSA with recombinant SOX1 protein. $\gamma \mathrm{A}$ oligonucleotide probe incubated without recombinant protein (in vitro transcription/ translation reaction mixture incubated without DN A template) (lane 1 ) or with SOX1 recombinant protein (lanes 2-7). Assays were done in the presence of nonspecific competitor (lane 2), nonradioactive $\gamma \mathrm{A}$ oligonucleotide (lane 3 ), nonradioactive mutated $\gamma \mathrm{AM}$ oligonucleotide (lane 4), normal rabbit serum (NRS) (lane 5), SOX1 rabbit antiserum abFB43 (lane 6), or ab791 (lane 7) as shown. $(\rightarrow)$ The position of SOX1 complex. 
of primers and distinguished by overnight digestion with BglII, which cuts only $\gamma \mathrm{E}$ and not $\gamma \mathrm{F}$ PCR products. $\alpha \mathrm{A}$-crystallin has two kinds of transcripts that give two PCR products of $365 \mathrm{bp}$ and $434 \mathrm{bp} ; \alpha \mathrm{B}-, 500 \mathrm{bp}$; BA 3/A 1-, 466 bp; $\gamma \mathrm{A}-$-, 419 bp; $\gamma \mathrm{B}-, 366$ bp; $\gamma \mathrm{C}-, 253$ bp; $\gamma \mathrm{D}-, 197$ bp; $\gamma \mathrm{EF}-$ 252 bp; $\gamma \mathrm{E}$-digested with BgllI, 149 and 103 bp; hprt, 702 bp.

In vitro transcription/translation and EMSA

The pIVTMSOX1 vector was constructed by inserting the blunt-ended Kpnl-Stul fragment into the blunt-ended Bglll site of pSP64T (Promega), which was modified to contain $3^{\prime}$ globin sequence for RNA stability. TnT-coupled reticul ocyte lysate system (Promega) was used according to the manufacturer's instructions. For EMSA, 33 fmoles of DNA radiolabeled with the Klenow fragment of DNA polymerase (NEB) was incubated with $1 \mu \mathrm{l}$ of in vitro transcription/translation reaction mixture containing SOX1 protein in a final volume of $10 \mu \mathrm{l}$ containing $20 \mathrm{~mm}$ HEPES (pH 7.9), 15\% glycerol, $50 \mathrm{~mm} \mathrm{KCl}, 1 \mathrm{~mm} \mathrm{DTT,} 0.25 \mu \mathrm{g} / \mu \mathrm{l}$ poly[d(G-C)], 1 mm EDTA. A 100-fold excess of competitor doublestranded $\gamma \mathrm{A}$ or $\gamma \mathrm{AM}$ oligonucleotide was added at the start of the reaction. After $30 \mathrm{~min}$ at room temperature, $1 \mu \mathrm{l}$ of normal rabbit serum or rabbit anti-mouse SOX1 antiserum abFB43 or ab791 (rabbit polyclonal antiserum raised against a 10-residue peptide of the mouse SOX1 aminoterminal region) (SN PE N eosystem) was added and incubated for an additional $30 \mathrm{~min}$ at room temperature. Reactions were subjected to electrophoresis on $4 \%$ non-denaturing polyacrylamide gels and analyzed by autoradiography.

\section{Acknowledgments}

We thank Thomas Jessell for comments on the manuscript and Steve Sheardown for providing materials and advice for the EMSAs. We also thank other members of the Embryology and $X$ Inactivation Iaboratories for helpful discussions and encouragement. The work was supported by the MRC.

The publication costs of this article were defrayed in part by payment of page charges. This article must therefore be hereby marked "advertisement" in accordance with 18 USC section 1734 solely to indicate this fact.

\section{References}

Brady, J.P., D. Garland, Y. Douglas Tabor, W.G. Robison, Jr., A. Groome, and E.F. Wawrousek. 1997. Targeted disruption of the mouse $\alpha A$ crystallin gene induces cataract and cytoplasmic inclusion bodies containing the small heat shock protein $\alpha$ B-crystallin. Proc. Natl. Acad. Sci. 94: 884-889.

Cartier, M., M.L. Breitman, and L.C. Tsui. 1992. A frameshift mutation in the $\gamma \mathrm{E}$-crystallin gene of the Elo mouse. Nature Genet. 2: 42-45.

Collignon, J. 1992. "Study of a new family of genes related to the mammalian testis determining gene," Ph.D. Thesis. Council for $\mathrm{N}$ ational A cademic A wards and $\mathrm{N}$ ational institutes for M edical Research, London, UK.

Collignon, J., S. Sockanathan, A. Hacker, M. Cohen Tannoudji, D. N orris, S. Rastan, M. Stevanovic, P.N. Goodfellow, and R. Lovell-Badge. 1996. A comparison of the properties of Sox-3 with Sry and two related genes, Sox-1 and Sox-2. Development 122: 509-520.

C vekl, A. and J. Piatigorsky. 1996. Lens devel opment and crystallin gene expression: Many roles for Pax-6. BioEssays 18: 621-330.

Dasgupta, S., T.C. Hohman, and D. Carper. 1992. Hypertonic stress in duces $\alpha$ B-crystallin expression. Exp. Eye Res. 54: 461-470.

de Jong, W.W. 1981. Evolution of lens and crystallins. In Molecular and cellular biology of the eye lens (ed. H. Blomendal), pp. 221-278. Wiley, New York, NY.

Everett, C.A., P.H. Glenister, D.M. Taylor, M.F. Lyon, J. Kratochvilova Loester, and J. Favor. 1994. M apping of six dominant cataract genes in the mouse. Genomics 20: 429-434.

Foster, J.W., M .A. Dominguez-Steglick, S. Guioli, G. Kwok, P.A. Weller, M. Stevanovic, J. Weissenbach, S. Mansour, I.D. Young, P.N. Good fellow, J.D. Brook, and A.J. Schafer. 1994. Campomelic Dysplasia and autosomal sex reversal caused by mutations in an SRY related gene. Nature 372: 525-530.

Glaser, T., L. Jepeal, J.G. Edwards, S.R. Young, J. Favor, and R.L. Maas. 1994. PAX6 gene dosage effect in a family with congenital cataracts, aniridia, anophthalmia and central nervous system defects. Nature Genet. 7: 463-471.
Goring, D.R., M.L. Breitman, and L.C. Tsui. 1992. Temporal regulation of six crystallin transcripts during mouse lens development. Exp. Eye Res. 54: 785-795.

Gubbay, J., J. Collignon, P. Koopman, B. Capel, A. Economou, A. Munsterberg, N. Vivian, P. Goodfellow, and R. Lovell-Badge. 1990. A gene mapping to the sex determining region of the mouse $Y$ chromosome is a member of a novel family of embryonically expressed genes. Nature 346: 245-250.

Hal der, G., P. Callaerts, and W.J. Gehring. 1995. Induction of ectopic eyes by targeted expression of the eyeless gene in Drosophila. Science 267: 1788-1792.

Hill, R.E., J. Favor, B.L. Hogan, C.C. Ton, G.F. Saunders, I.M. Hanson, J. Prosser, T. Jordan, N.D. Hastie, and V. van Heyningen. 1991. M ouse small eye results from mutations in a paired-like homeobox-containing gene. Nature 354: 522-525.

Horwitz, J. 1992. $\alpha$-crystallin can function as a molecular chaperone. Proc. Natl. Acad. Sci. 89: 10449-10453.

Kamachi, Y., S. Sockanathan, Q. Liu, M. Breitman, R. Lovell-Badge, and H. Kondoh. 1995. Involvement of SOX proteins in lens-specific activation of crystallin genes. EMBO J. 14: 3510-3519.

Lok, S., M.L. Breitman, and L.-C. Tsui. 1989. Multiple regulatory ele ments of the murine $\gamma 2$-crystallin promoter. Nucleic Acids Res. 17: 3563-3582.

Lubsen, N.H., J.H. Renwick, L.C. Tsui, M.L. Breitman, and J.G. Schoenmakers. 1987. A locus for a human hereditary cataract is closely linked to the $\gamma$-crystallin gene family. Proc. Natl. Acad. Sci. 84: 489492.

Malas, S., S.M. Duthie, F. Mohri, R. Lovell-Badge, and V. Episkopou. 1997. Cloning and mapping of the human SOX1: A highly conserved gene expressed in the developing brain. Mamm. Genome 8: 866-868.

McAvoy, J.W. 1978. Cell division, cell elongation and the co-ordination of crystallin gene expression during lens morphogenesis in the rat. J. Embryol. Exp. Morphol. 45: 271-281.

Oliver, G. and P. Gruss. 1997. Current views on eye devel opment. Trends Neurosci. 20: 415-421.

Parmelee, J.T. and D.C. Beebe. 1988. Decreased membrane permeability to potassium is responsible for the cell volume increase that drives Iens fiber cell elongation. J. Cell Physiol. 134: 491-496.

Pevny, L.H. and R. Lovell-Badge. 1997. Sox genes find their feet. Curr. Opin. Genet. Dev. 7: 338-344.

Piatigorsky, J. and G.J. Wistow. 1989. Enzyme/crystallins: Gene sharing as an evolutionary strategy. Cell 57: 197-199.

Schilham, M.W., M.A. Oosterwegel, P. M oerer, J. Ya, P.A. de Boer, M. van de Wetering, S. Verbeek, W.H. Lamers, A.M. Kruisbeek, A. Cumano, and $\mathrm{H}$. Clevers. 1996. Defects in cardiac outflow tract formation and pro-B-Iymphocyte expansion in mice lacking Sox-4. Nature 380: 711714.

Streit, A., S. Sockanathan, L. Perez, M. Rex, P.J. Scotting, P.T. Sharpe, R. Lovell-Badge, and C.D. Stern. 1997. Preventing the loss of compe tence for neural induction: HGF/SF, L5 and Sox-2. Development 124: 1191-1202.

Ton, C.C., H. Hirvonen, H. Miwa, M.M. Weil, P. Monaghan, T. Jordan, V. van Heyningen, N.D. Hastie, H. Meijers-Heijboer, M. Drechsler et al. 1991. Positional cloning and characterization of a paired box- and homeobox-containing gene from the aniridia region. Cell 67: 10591074.

Uwanogho, D., M. Rex, E.J. Cartwright, G. Pearl, C. Healy, P.J. Scotting, and P.T. Sharpe. 1995. Embryonic expression of the chicken Sox2, Sox3, and Sox11 genes suggests an interactive role in neuronal development. Mech. Dev. 49: 23-36.

Wistow, G.J. and J. Piatigorsky. 1988. Lens crystallins: the evolution and expression of proteins for a highly specialized tissue. Annu. Rev. Biochem. 57: 479-504. 


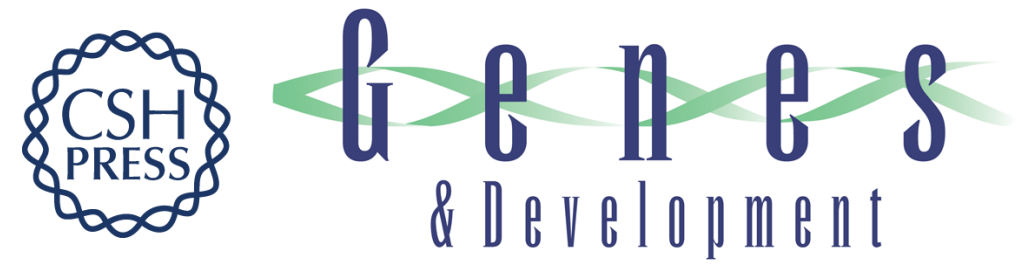

\section{Sox1 directly regulates the $\gamma$-crystallin genes and is essential for lens development in mice}

Seiji Nishiguchi, Heather Wood, Hisato Kondoh, et al.

Genes Dev. 1998, 12:

References This article cites 27 articles, 6 of which can be accessed free at: http://genesdev.cshlp.org/content/12/6/776.full.html\#ref-list-1

License

Email Alerting

Receive free email alerts when new articles cite this article - sign up in the box at the top Service right corner of the article or click here.

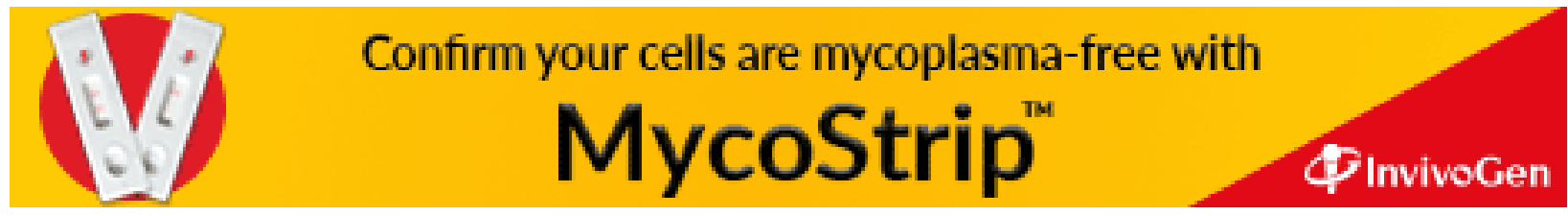

